\title{
Deciding a Multicriteria Decision-Making (MCDM) Method to Prioritize Maintenance Work Orders of Hydroelectric Power Plants
}

\author{
Renan Favarão da Silva ${ }^{1, *(\mathbb{D})}$, Marjorie Maria Bellinello ${ }^{2} \mathbb{D}$, Gilberto Francisco Martha de Souza ${ }^{1, *(D)}$, \\ Sara Antomarioni ${ }^{3}$ (D) , Maurizio Bevilacqua ${ }^{3}\left(\mathbb{D}\right.$ ) and Filippo Emanuele Ciarapica ${ }^{3}$ \\ 1 Department of Mechatronics and Mechanical Systems Engineering, University of São Paulo (USP), \\ São Paulo 05508-900, Brazil \\ 2 Department of Mechanical and Maintenance Engineering, Federal University of Technology of \\ Paraná (UTFPR), Guarapuava 85053-525, Brazil; belinelli@utfpr.edu.br \\ 3 Department of Industrial Engineering and Mathematical Sciences, Marche Polytechnic University (UNIVPM), \\ Via Brecce Bianche, 60131 Ancona, Italy; s.antomarioni@pm.univpm.it (S.A.); m.bevilacqua@univpm.it (M.B.); \\ f.e.ciarapica@univpm.it (F.E.C.) \\ * Correspondence: renanfavarao@usp.br (R.F.d.S.); gfmsouza@usp.br (G.F.M.d.S.)
}

\section{check for} updates

Citation: da Silva, R.F.; Bellinello, M.M.; de Souza, G.F.M.; Antomarioni, S.; Bevilacqua, M.; Ciarapica, F.E. Deciding a Multicriteria

Decision-Making (MCDM) Method to Prioritize Maintenance Work Orders of Hydroelectric Power Plants. Energies 2021, 14, 8281. https://doi. org/10.3390/en14248281

Academic Editor: Fausto Pedro García Márquez

Received: 11 October 2021

Accepted: 18 November 2021

Published: 8 December 2021

Publisher's Note: MDPI stays neutral with regard to jurisdictional claims in published maps and institutional affiliations.

Copyright: (c) 2021 by the authors. Licensee MDPI, Basel, Switzerland. This article is an open access article distributed under the terms and conditions of the Creative Commons Attribution (CC BY) license (https:/ / creativecommons.org/licenses/by/ $4.0 /)$.
Abstract: The current global competitive scenario and the increase in complexity and automation of equipment and systems demand better results from maintenance management in organizations. As maintenance resources are limited, prioritizing maintenance activities is essential to allocate them properly and to meet maintenance management objectives. In the face of these challenges, multicriteria decision-making (MCDM) methods are commonly used in organizations to support decision-making. Nevertheless, selecting a suitable MCDM method for maintenance planning can be complicated given the diversity of methods and their strengths and weaknesses. In this context, this paper proposes a novel knowledge-based method for deciding a multicriteria decisionmaking (MCDM) method to prioritize maintenance work orders of hydroelectric plants. As the main novel contribution, it translates the intrinsic characteristics of the main MCDM methods into questions related to maintenance planning to guide the recommendation of a suitable MCDM method for organizations through a decision tree diagram. This approach was applied to a maintenance case study of a hydroelectric power plant in order to demonstrate its use and contribute to its understanding. These findings contribute to maintenance management in selecting an MCDM method aligned with the context of its maintenance planning for the prioritization of maintenance work orders.

Keywords: maintenance; maintenance planning; prioritization; multicriteria decision-making; MCDM; MCDM method selection; hydroelectric power plant

\section{Introduction}

The current economic scenario and global competitiveness force companies to invest more resources in strengthening their production processes and support systems to maintain stability and create competitive advantages in organizations [1]. As maintenance is one of the key levers to deliver business outcomes [2], the challenges of intense international competition have created pressure for better results [3]. Therefore, it has become part of the overall profitability of an organization and has played an important role in supporting business and operation strategies $[4,5]$.

Nevertheless, maintenance management of modern production engineering systems is not just about the restoration of the physical assets to their operational state after a failure. As a supporting process in business, it encompasses the planning, organization, implementation, and control of all maintenance activities [6]. Moreover, it is becoming an 
increasingly important and complex process, especially given the increasing automation and reduced production margin in the global market [1].

In other words, maintenance is one of the main stages to realize value from physical assets in asset management. According to ISO 55000 [7], asset management typically involves balancing costs, opportunities, and risks against the desired performance of assets to achieve organizational objectives. Accordingly, the organization shall determine the method and criteria for decision-making and prioritizing the activities and resources to achieve its asset management plans when planning how to achieve its objectives [7]. Nevertheless, this undertaking is not as simple as it seems.

Although the ISO 55000 series for asset management provides international guidance on best practices applicable throughout the asset's life cycle, they are not specific. As this series of standards only prescribes what needs to be implemented and not how these requirements should be fulfilled, many organizations struggle with these topics. In other words, organizations may face barriers in interpreting the requirements defined in the asset management guidelines, which makes it difficult to choose and implement suitable methods for their context [8]. In addition, there are few academic publications for reference covering the ISO 55000 series [9].

Regarding maintenance management, the prioritization of maintenance activities and resources is essential for the achievement of asset management objectives. According to ISO 550001 [10], the organization is responsible for providing the resources required for meeting these objectives and for implementing the activities specified in the asset management plans. As these resources are limited, appropriately allocating them according to the priorities and the organizational context is of interest to organizations.

In this context, this paper aims to propose a novel knowledge-based method for deciding on a multicriteria decision-making (MCDM) method to prioritize maintenance work orders of hydroelectric plants. It intends to use a decision tree diagram to guide the professionals responsible for prioritizing maintenance work orders on the most appropriate MCDM method for their maintenance contexts. For this purpose, the intrinsic characteristics of the main MCDM methods were reviewed and translated into questions related to maintenance planning to guide the recommendation of a suitable MCDM method for organizations. This is a novel contribution since the proposed method considers aspects of the maintenance context instead of features of the MCDM methods. It is demonstrated through a maintenance case study application in a Brazilian hydroelectric power plant.

Decision analysis enables decision makers to structure their thinking, explore tradeoffs between attributes, and deliver a documented and defensible rationale for a given decision [11]. These benefits are relevant to maintenance planning, as it entails complex decisions such as "which maintenance work orders should be prioritized to best optimize maintenance results?" It is no longer a simple and technical decision, and it needs to be supported as different criteria need to be considered. Therefore, discussing a novel method for deciding an MCMD method to support resource allocation in maintenance planning is pertinent to practitioners and researchers of the maintenance field and for the theme of this paper.

The remainder of the paper is structured as follows: Section 2 provides an overview of support for maintenance decision-making. Section 3 presents the proposed decision tree diagram for deciding an MCDM method prioritized towards work orders of hydroelectric power plants. Section 4 applies the method to a maintenance context of the case of a hydroelectric power plant and Section 5 discusses its findings. Finally, Section 6 presents the authors' conclusions about the proposed method and case study.

\section{Support for Maintenance Decision-Making}

In the industrial environment, maintenance is a strategic process that directly influences the performance of operational availability. Nevertheless, decisions regarding industrial maintenance are complex, since they commonly deal with several criteria of qualitative, quantitative, and mixed natures. Accordingly, as the decisions involved in the 
maintenance process can contribute to the optimization of maintenance management and the achievement of asset management objectives, it is expected that decision makers will make aided decisions for more assertive decisions in maintenance management.

Unaided maintenance management decisions can lead to delays and make maintenance more costly for organizations [12]. In addition to dealing with specialized labor and technical spare parts, maintenance can impact productivity due to the reliability and maintainability of physical assets $[13,14]$. Regarding hydroelectric power plants, unexpected failures of physical assets can lead to the interruption of energy generation. Moreover, in interconnected and regulated electricity production and transmission systems, such as in Brazil, the unavailability or poor availability of a hydroelectric plant may impact the activation of other non-renewable energy generation sources. Accordingly, maintenance management performance is fundamental to control the several risks associated with physical assets and to ensure a safe operation.

The application of multicriteria decision-making (MCDM) methods aims to identify the optimal alternative among a finite set of alternatives to support decision-making in organizations. This approach allows possible alternatives to be ranked, e.g., from the best to the worst, based on the evaluation of the performance of the alternatives in each of the criteria. However, although several MCDM methods have been developed to solve problems, the recent literature still lacks specific applications of these techniques to the maintenance context in the industrial sector.

Regarding maintenance planning, prioritizing maintenance work orders for maintenance schedules is a critical task. As can be seen in Figure 1, it integrates a maintenance work order execution process in maintenance management. By effectively classifying pending maintenance work orders in terms of priorities, maintenance planners can optimize the allocation of human, material, and financial resources aligned to maintenance and asset management objectives.

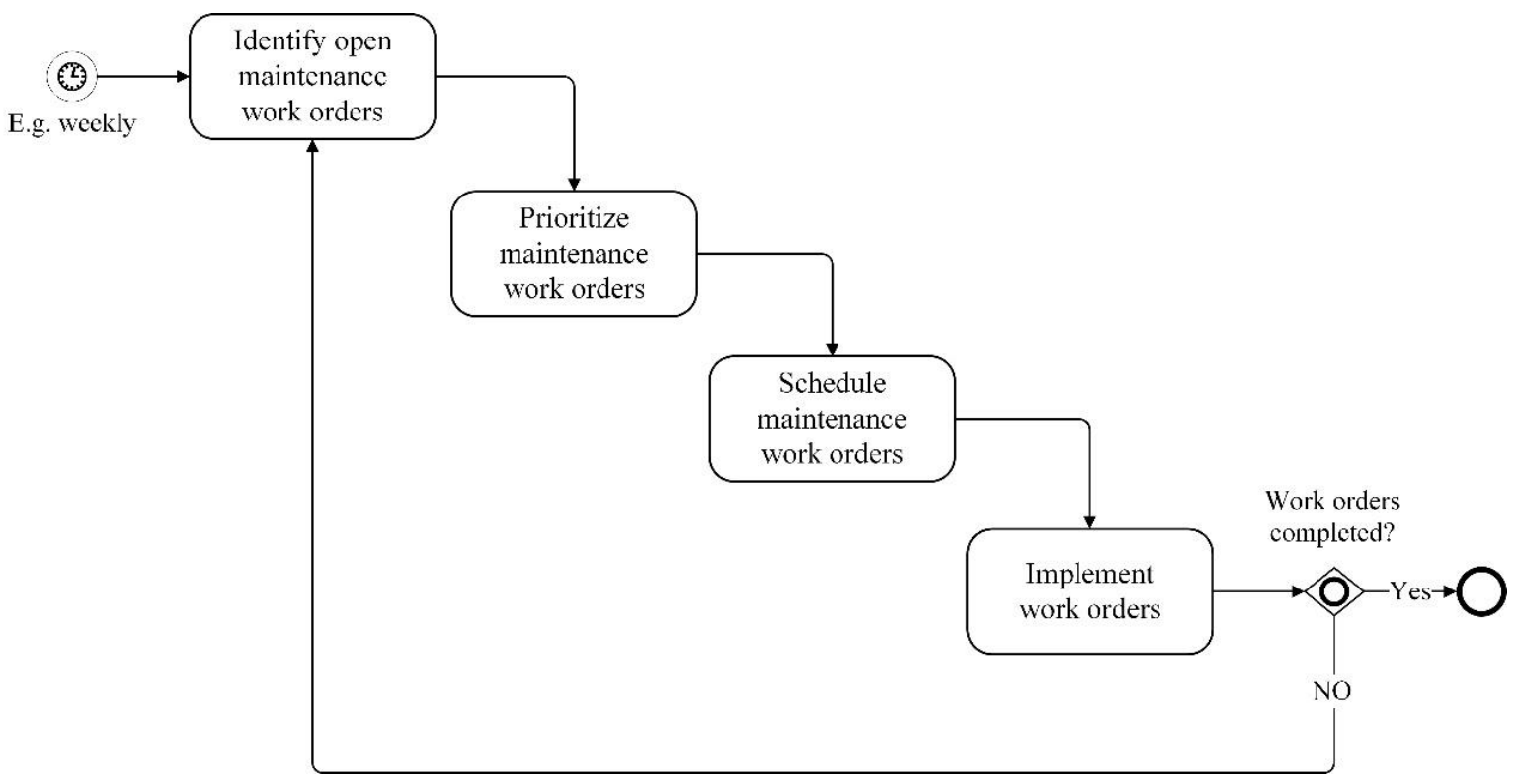

Figure 1. Simplified process for executing maintenance work orders.

The selection of a decision support method to prioritize maintenance work orders appears to be a relevant application for maintenance management. Nevertheless, since several MCDM methods have been developed, it becomes difficult for maintenance professionals to choose the method that is most recommended and adherent to their context. Accordingly, this aligns with the proposed method in this paper as it aims to guide the choice of an appropriate MCDM method to assist in maintenance planning decisions. 
The material and methods for maintenance decision-making are presented in the three following subsections. First, Section 2.1. provides an overview of the most used multicriteria decision-making (MCDM) methods in the literature. In Section 2.2., considerations for selecting an MCDM method according to the application context were discussed.

\subsection{Main MCDM Methods}

Decision-making processes are usually complex because they encompass several criteria that are often conflicting with each other. As previously presented, decision support methods can guide decision makers to the optimal alternatives through the result of different mathematical models.

In order to identify the main MCDM methods, a literature review was carried out in April 2020 on the Web of Science Core Collection, as it is one of the most relevant scientific production databases. Documents with terms "MCDM" or "MCDA" in their title, abstract, or keywords were searched in the database of the last 15 years (2005-2019). Articles, reviews, and editorial materials, including those in early access, were prioritized in the data collection due to relevance of these documents and the rigor of the review process.

A total of 5538 documents were selected and their keywords were grouped and sorted by occurrence. Thus, it was possible to observe which methods are the main MCDM methods in the literature, as presented in Table 1.

Table 1. The main MCDM methods in the literature.

\begin{tabular}{clc}
\hline$\#$ & Method & Occurrence \\
\hline 1 & Analytic Hierarchy Process (AHP) & 1286 \\
\hline 2 & $\begin{array}{l}\text { Technique for Order Preference by Similarity to Ideal Solution } \\
\text { (TOPSIS) }\end{array}$ & 816 \\
\hline 3 & Analytic Network Process (ANP) & 406 \\
\hline 4 & $\begin{array}{l}\text { VIseKriterijumska Optimizacija I Kompromisno Resenje } \\
\text { (VIKOR) }\end{array}$ & 380 \\
\hline 5 & $\begin{array}{l}\text { Preference Ranking Organization Method for Enrichment } \\
\text { Evaluations (PROMETHEE) }\end{array}$ & 196 \\
\hline 6 & Data Envelopment Analysis (DEA) & 69 \\
\hline 7 & The Elimination et Choix Traduisant la Realité (ELECTRE) & 54 \\
\hline 8 & Weighted Aggregated Sum Product Assessment (WASPAS) & \\
\hline
\end{tabular}

Accordingly, an overview of these MCDM methods, highlighting their features, strengths, and weaknesses, is shown in the following Table 2. The strengths and weaknesses of these methods are addressed in the literature, especially in articles reviewing the literature on MCDM methods. However, these discussions are done individually for each MCDM method. Accordingly, for this article, the reported advantages and disadvantages of these main MCDM methods were compiled in Table 2, accessing the results of several studies that addressed the MCDM methods [13,15-53]. These characteristics were then used to elaborate the questions in the proposed diagram. 
Table 2. Overview of the main MCDM methods in the literature.

\begin{tabular}{|c|c|c|c|c|}
\hline Method & Features & Strengths & Weaknesses & References \\
\hline AHP & $\begin{array}{l}\text { This method was developed by Thomas Saaty in the } \\
\text { 1970s and is currently one of the most popular MCDM } \\
\text { methods. The AHP evaluates the criteria as well as the } \\
\text { alternatives with respect to each criterion through } \\
\text { pairwise comparison. As result, it obtains a vector of } \\
\text { criteria weights and the priority vectors of the } \\
\text { alternatives for each of the criteria. These vectors are } \\
\text { synthesized to compose the global priority of } \\
\text { the alternatives. }\end{array}$ & $\begin{array}{l}\text { i. It calculates the inconsistency index which is } \\
\text { important to ensure the consistent judgments of } \\
\text { the decision makers; ii. Quick application } \\
\text { compared to other methods; iii. It converts a } \\
\text { complex problem into a simple, flexible and } \\
\text { intuitive hierarchy; iv. It is a powerful technique } \\
\text { when the criteria are independent. }\end{array}$ & $\begin{array}{l}\text { i. Loss of information due to the high level of } \\
\text { aggregation; ii. Difficulty in interpreting qualitative } \\
\text { scale (e.g., "strongly") due to human nature; iii. Its } \\
\text { accuracy can vary widely in subjective problems; } \\
\text { iv. The implementation is relatively inconvenient due } \\
\text { to its complexity; v. It is cognitively demanding; vi. It } \\
\text { is susceptible to the reversal of the classification; } \\
\text { vii. The qualitative pairwise comparisons may } \\
\text { imply uncertainty. }\end{array}$ & [15-18] \\
\hline TOPSIS & $\begin{array}{l}\text { This method is based on the calculation of the } \\
\text { Euclidean distance to evaluate the distance between } \\
\text { the ideal positive and negative solutions. Thus, the } \\
\text { final classification of the alternatives occurs both in the } \\
\text { shortest distance to the ideal positive solution and in } \\
\text { the longest distance from the negative one. }\end{array}$ & $\begin{array}{l}\text { i. It only depends on the weights and intrinsic } \\
\text { characteristics of each alternative; ii. Quick } \\
\text { application when compared to other MCDM } \\
\text { methods; iii. Consistent and reliable; iv. Easy to } \\
\text { implement and understandable principle; v. It } \\
\text { works satisfactorily in different areas } \\
\text { of application. }\end{array}$ & $\begin{array}{l}\text { i. Loss of information due to the high level of } \\
\text { aggregation; ii. It does not provide how to determine } \\
\text { the weights for the different criteria. It is assumed } \\
\text { that it already has this information; iii. The use of } \\
\text { Euclidean distance does not consider the correlation } \\
\text { of attributes. }\end{array}$ & {$[13,19-21]$} \\
\hline ANP & $\begin{array}{l}\text { This method was developed by Thomas Saaty as an } \\
\text { expansion of AHP based on the Markov Chain concept. } \\
\text { ANP mathematical modeling is characterized by a } \\
\text { decision system that overcomes the problem of the } \\
\text { interdependence of elements at all hierarchical levels } \\
\text { and within the same level. }\end{array}$ & $\begin{array}{l}\text { i. ANP has all the positive characteristics of AHP, } \\
\text { including simplicity, flexibility, simultaneous use } \\
\text { of quantitative and qualitative criteria, and the } \\
\text { ability to review consistency in judgments; ii. It } \\
\text { allows for dependence and includes } \\
\text { independence and it has the ability to prioritize } \\
\text { groups or clusters of elements. }\end{array}$ & $\begin{array}{l}\text { i. It is sensitive to several criteria. As the number of } \\
\text { criteria increases, the dimensions of the super } \\
\text { matrices increase, which leads to the extension } \\
\text { and/or impossibility of the resolution process; ii. The } \\
\text { qualitative nature of comparisons made in pairs may } \\
\text { imply uncertainty; iii. It also has the same } \\
\text { weaknesses of the AHP. }\end{array}$ & [22-25] \\
\hline VIKOR & $\begin{array}{l}\text { From Serbian, VIKOR means "Multi-Criteria } \\
\text { Optimization and Compromise Solution. It was } \\
\text { developed by Serafim Opricovic and it aims to solve } \\
\text { decision problems with conflicting criteria, through a } \\
\text { viable compromise solution obtained by the data input } \\
\text { (weights and criteria). }\end{array}$ & $\begin{array}{l}\text { i. It is tolerant of deviations in values during the } \\
\text { evaluation period; ii. Its algorithm can be } \\
\text { performed without the interactive participation } \\
\text { of decision makers. }\end{array}$ & $\begin{array}{l}\text { i. Possible errors in calculation; ii. Linear } \\
\text { normalization is necessary to solve multidimensional } \\
\text { problems of criteria; iii. It does not provide how to } \\
\text { determine the weights for the different criteria. }\end{array}$ & {$[26,27]$} \\
\hline
\end{tabular}


Table 2. Cont.

\section{Method}

\section{Features}

It was first introduced by J.P. Brans in the 1980s. It is a

method of the outranking family with

non-compensatory characteristics and consists of a preference function associated with each criterion,

PROMETHEE with the weights describing their relative importance.

The initial definition of the method has distinguished

between standards for a partial classification of

alternatives (PROMETHEE I) or complete

(PROMETHEE II). Then, later studies have created other extensions (III, IV, V, and VI).

Unlike most existing MCDMs, it does not use a common set of weights that can express the preferences of a decision maker. DEA mathematical modeling is based on the application of the linear programming technique to evaluate the relative efficiency of each alternative on a judgment scale ranging from 0 to 1 . It identifies relationships between variables that other methods are not able to perform.

i. It is easy to use and of low complexity; ii. It is particularly useful when there are difficulties in reconciling alternatives; iii. The advantages of this method are clarity and stability; iv. You can use qualitative and quantitative data.

i. It does not use modeled preference information (e.g., weights or utility function); ii. It is capable of handling multiple inputs and outputs and it can discover relationships that may be hidden with other methods; iii. It can even be used for a pre-analysis, identifying the main efficient

alternatives, and then applying a conventional MCDM method.

From French, ELECTRE means "Elimination and Choice Expressing Reality. It is a consistent MCDM belonging to the outranking family. Outranking are non-compensatory methods that were developed for situations in which there are a large number of alternatives with strong heterogeneity between criteria. Among its extensions, ELECTRE IV stands out as it does not use a common set of weights.

It is an elementary and compensatory multicriteria method introduced by E.K. Zavadskas. It is the only method that was developed by combining two

WASPAS i. It is applicable even when information is missing; ii. It can use qualitative and quantitative data; iii. Weights are used as coefficients of importance so that compensation is not implied iv. Its main advantage is that it takes into accoun uncertainty and imprecision.

i. It consists of two mathematically-based techniques combined, WSM and WPM; ii. It is quite comprehensive in nature and it can be successfully applied to any decision-making situation; iii. It involves a simple and solid mathematical model.

\section{Weaknesses}

References

i. Concerns with this method are centered on the dependence of quite arbitrary definitions of what constitutes outranking and the lack of axiomatic bases; ii. Very long computation process compared to other MCDM methods; iii. The method does not provide how to determine the weights for the different criteria; iv. It is difficult for the user to get a clear view of the problem when using many criteria.

i. It does not deal with inaccurate data and assumes that all input and output data is exactly known. ii. It does not use a set of weights that express the preferences of the decision maker. iii. The user may not understand the logic and assumptions of the method for accepting them; iv. An efficient alternative in DEA could be the best or the worst compromise solution in an aggregation method.

i. Concerns with this method are centered on the dependence of quite arbitrary definitions of what constitutes outranking and the lack of axiomatic bases; ii. Very long computation process compared to other MCDM methods; iii. The method only draws attention to preference and ignores the level of difference between alternatives; iv. It consumes time without using specific software; v. It is considered quite difficult;

i. Possible errors in calculation; ii. There is no consistency analysis process for the input data, so input data must be reliable for the result to be mathematical modeling and consistent result, it has been applied in the solution of many problems in several areas. 


\subsection{Selecting an MCDM Method}

Some key factors appear to influence the decision-makers in selecting the support for decision-making. Among them are the time available to make a decision, the effort that a given strategy will involve, the importance of making an accurate decision, and whether or not the user has to justify his or her choice to others [11]. For organizations that seek competitiveness, choosing an appropriate MCDM method to improve their maintenance outcomes has a vital role [46].

In an unaided decision-making process, decision makers tend to use basic heuristics and biased prior knowledge to define their best solutions [11]. Besides, preferences may consider subjective criteria and not just technical criteria or historical data to compare possible solutions. Accordingly, the application of an MCDM method can assist the decision-making process through a comprehensive analysis that encompasses the important properties for decision-making.

Nevertheless, different decision-making methods have been developed over time with different mathematical approaches. The application of two different MCDM methods can even provide different outputs for the same problem, although they are not significant [54]. As the MCDM methods have their strengths and weaknesses, as presented in Table 2, it can be difficult for someone to select an assertive MCDM method concerning its studied context. In addition, few studies have addressed the selection of a suitable MCDM method to the relevant problem in the literature.

Guitouni and Martel presented initial studies on models for choosing the appropriate MCDM method for a specific decision-making situation based on comparisons of several MCDM methods over different guidelines [55]. Leite and Freitas developed a simple decision flowchart for choosing between three decision methods, AHP, PROMETHEE, and ELECTREE. This proposed flowchart was structured considering, primarily, the characteristics of the criteria in the problem [56]. Sabaei, Erkoyuncu, and Roy proposed a simple decision flowchart based on the decision makers' preference to recommend a support method for decision-making [46]. Haddad et al. presented a methodology to automatically recommend the most appropriate MCDM by evaluating features of the problem and the method through a software interface [54,57].

In this paper, the novel knowledge-based method for choosing an MCDM method is based on a decision tree diagram and it takes into account the maintenance planning context of an organization. Unlike other articles in the literature, this proposed approach considers technical information of the maintenance planning rather than intrinsic characteristics of the MCDM methods to guide the recommendation of suitable methods for application in the organization. This contributes to the ease of use of the method by practitioners since it uses a maintenance language instead of technical terms in the area of decision-making.

\section{The Proposed Decision Tree Diagram for Deciding an MCDM Method to Prioritize Maintenance Work Orders}

This paper proposes a novel knowledge-based method based on a decision tree diagram for deciding an MCDM method to apply for maintenance work order (MWO) prioritizations of hydroelectric power plants. Through questions about the maintenance planning context, the diagram recommends suitable MCDM methods for an organization. It is represented in Figure 2 and discussed in detail in the following subsections.

\subsection{Using the Diagram}

The proposed diagram comprises a set of five distinct questions that were designed to translate the strengths and weaknesses of the MCDM methods reported in the literature into the context of maintenance planning, as shown in Table 3 and discussed afterwards. In addition, these questions were sufficient for the proposed diagram to differentiate and recommend suitable MCDM methods. Depending on the answers to them, the user is directed to different MCDM methods at the end of the proposed decision tree diagram. Accordingly, 
answering these questions appropriately is essential for recommending an MCDM method to prioritize maintenance work orders in the appropriate operational context.

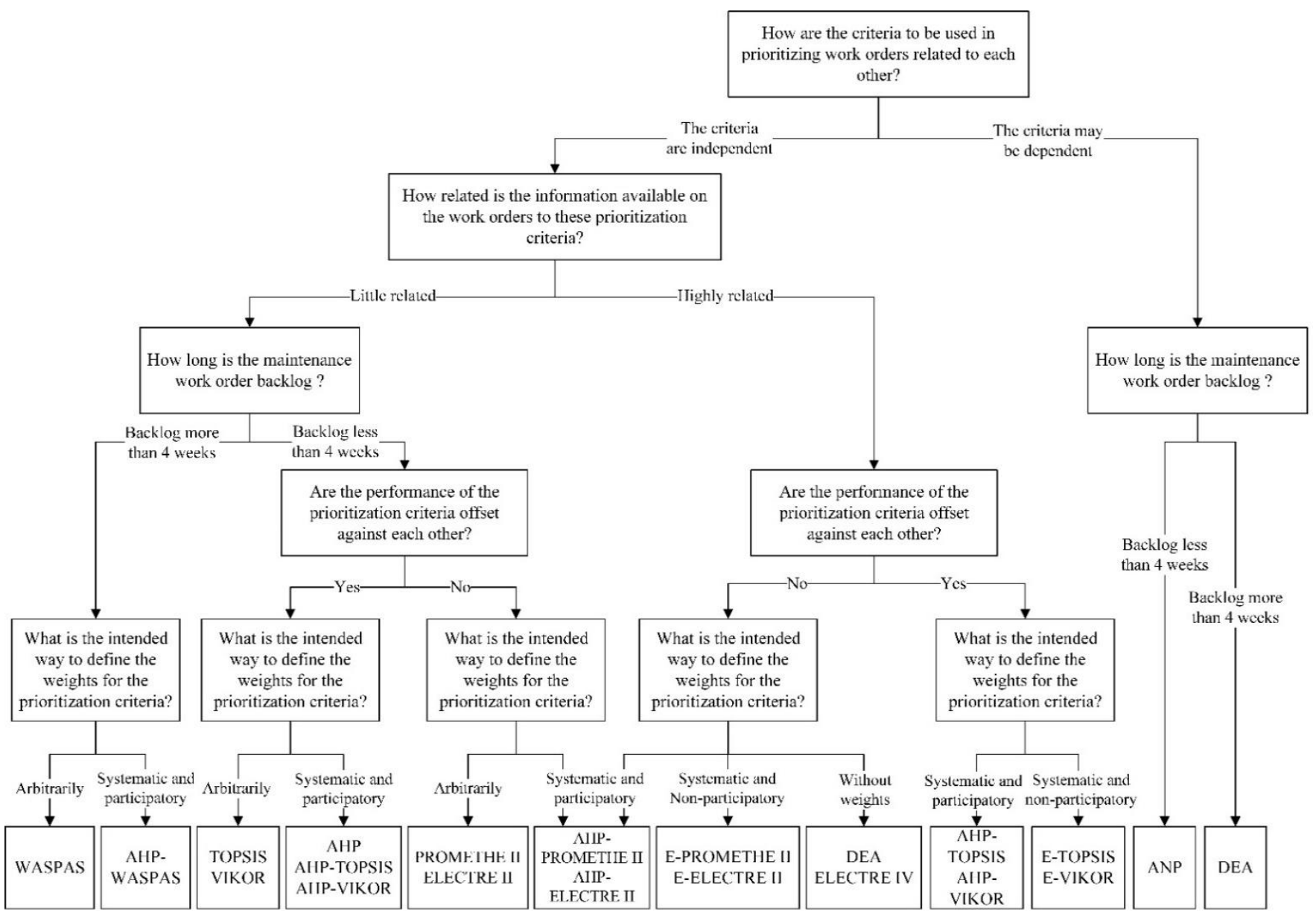

Figure 2. The proposed decision tree diagram.

Table 3. Questions and possible answers in the proposed decision diagram.

\begin{tabular}{lll}
\hline$\#$ & Question & Possible Answer Options \\
\hline 1 & $\begin{array}{l}\text { How are the criteria to be used in prioritizing work orders } \\
\text { related to each other? }\end{array}$ & $\begin{array}{l}\text { The criteria are independent } \\
\text { The criteria can be dependent }\end{array}$ \\
\hline 2 & $\begin{array}{l}\text { How related is the information available on the work } \\
\text { orders to these prioritization criteria? }\end{array}$ & $\begin{array}{l}\text { Little related } \\
\text { Highly related }\end{array}$ \\
\hline 3 & How long is the maintenance work order backlog? & $\begin{array}{l}\text { Backlog more than 4 weeks } \\
\text { Backlog less than 4 weeks }\end{array}$ \\
\hline 4 & $\begin{array}{l}\text { Are the performance of the prioritization criteria offset } \\
\text { against each other? }\end{array}$ & $\begin{array}{l}\text { Yes } \\
\text { No }\end{array}$ \\
\hline & $\begin{array}{l}\text { What is the intended way to define the weights for the } \\
\text { prioritization criteria? }\end{array}$ & $\begin{array}{l}\text { Arbitrary } \\
\text { Systematic and participatory (with AHP) } \\
\text { Systematic and non-participatory (with Entropy) } \\
\text { Without weights }\end{array}$ \\
\hline
\end{tabular}

Since each MCDM method has its strengths and weaknesses, as well as different mathematical approaches, these methods can vary in different degrees of complexity, need for information, and need for resources, such as computational support or execution time. Thus, it is of interest that the questions in the diagram assist the decision maker to select an 
MCDM method that best suits its application. In the proposed diagram, the questions are intended to direct the user to the MCDM methods that optimize the resources available in maintenance planning. In other words, the complex MCDM method tends not to be recommended to prioritize MWOs in maintenance planning contexts that are not prepared for it. When analyzing the questions individually, this recommendation premise becomes more evident.

In the first question, the decision-maker informs how the criteria to be used for prioritizing work orders are related to each other. These criteria usually reflect the needs and expectations of maintenance planning in order to contribute to the achievement of maintenance management objectives. In general, most MCDM methods treat the criteria independently and this can be evidenced in the proposed diagram by the number of ramifications from the criteria independence answer in question 1. If these criteria are dependent on each other, the user is directed to more complex MCDM methods, as shown on the right side of Figure 2.

Question 2 was designed to identify the availability of the information needed to evaluate work orders in each of the criteria. When the organization has a computerized maintenance management system (CMMS) that supports maintenance planning, the information available on maintenance work orders can be used directly as a criterion or to evaluate the selected criteria. In other scenarios, the availability and reliability of information is an additional complexification to the work order prioritization process and, therefore, the diagram will tend to recommend simpler MCDM methods.

This reasoning was also replicated in the third question, where the number of work orders for prioritization is directly related to the time of the evaluation of the criteria for each of these orders, especially in cases of little relation between the information available and that needed to assess the criteria. To guide the answer to this question, the user can use the maintenance backlog to check how long the maintenance work order backlog in its context is. A backlog longer than about four weeks can be considered excessive, while less than that means a low number of work orders [6].

In the fourth question, the decision maker needs to inform how the performances of the selected criteria relate to each other. In other words, this question aims to assess whether the compensation between the performance of the criteria is pertinent. Therefore, depending on the answer, the diagram recommends compensatory or non-compensatory methods. The first is based on the concept that the criteria can be normalized on the same scale and compared using weights as a measure of relative importance for the aggregation in a single score. On the other hand, the latter considers that the compensation of loss in one criterion for gain in another is unacceptable, usually when there is a large number of alternatives with strong heterogeneity between criteria, and builds an outranking relation to guide the best solution [46,58].

Finally, question five aims to express the preferences of the decision-maker regarding the definition of the weights of the prioritization criteria for the pre-recommended MCDM methods through the answers to the previous questions. Among the possible answers are arbitrary, systematic and participatory, and systematic and non-participatory weighing, as well as the non-use of weights. As can be seen in Figure 2, the diagram only recommends hybrid MCDM methods in cases where the decision-maker wants to improve the decisionmaking process with the combination of an additional and systematic approach to specify preferences between the criteria that are required in the recommended MCDM method. In a participatory approach, the method recommends integration with the AHP while, in a non-participatory approach, it recommends integration with an entropy analysis (E). Otherwise, the diagram guides the user to approach a pure MCDM method.

\subsection{Other Points to Consider}

Although the proposed diagram translates important characteristics of the MCDM methods in its questions in order to recommend an MCDM method, the normalization techniques or uncertainties of the performance evaluations in the criteria are not addressed. 
Thus, it is appropriate to discuss these points in this section to make the decision-maker aware of the impacts on his decision-making process.

Regarding data normalization, it is common for MCDM methods to address this in their different mathematical approaches since the units of measurement may be different in the collected data and the understanding of variations depends on a mathematical transformation. This transformation is usually called normalization and focuses on understanding the dispersion between the mean, allowing visualization of the different units in an equivalent way $[59,60]$.

The main MCDM methods covered in this article do not use the same standardization technique. In fact, many techniques exist to normalize data in the literature. Jahan and Edwards identified 31 techniques that were applied to normalize the criteria attributes related to decision-making in engineering, civil construction, and financial projects. Moreover, they showed that previous statistical analysis of the data can suggest an appropriate normalization technique [61]. For example, the logarithmic normalization technique is more appropriate when there are variables with different units, in which the values of the criteria differ considerably [59-62].

The decision-maker needs to be aware that normalization techniques have not been addressed in the proposed diagram. If necessary, the recommended MCDM method for prioritizing the maintenance work orders will present a data normalization technique throughout its mathematical approach. Accordingly, it is appropriate that the user adopts the normalization technique intrinsic to the MCDM method if no data study will be performed to verify the adherence of the data to the normalization techniques.

In many decision problems, the evaluation of alternatives is complicated by their performance in at least some attributes that are not known with certainty [48]. Regarding this uncertainty during decision-making, the fuzzy theory is combined with the main MCDM methods to solve this problem [63]. In other words, fuzzy decision-making is used where vague and incomplete data exist for the solution $[64,65]$.

Therefore, the decision-maker also needs to be aware that the proposed diagram does not consider the uncertainty in performance evaluation of the maintenance work orders across the criteria in its recommendation. The combination of the chosen MCDM method with techniques that deal with uncertainty, such as the fuzzy theory and its variations, is at the discretion of the decision-maker based on the information collected for decision-making. Accordingly, in face of uncertainty issues, it is appropriate that the user treat them in a variation of the recommended MCDM method by the proposed diagram.

\section{Case Study}

In this paper, the proposed method was applied to a maintenance planning case study in order to demonstrate its use and contribute to its understanding. A hydroelectric power plant composed of 4 Kaplan turbine generating units and around 200 MW of capacity in Brazil was selected for this purpose. Hydroelectric plants are of great importance in Brazil due to the predominance of this type of energy in its energy matrix. Furthermore, this plant, in specific, has been undergoing studies and changes for asset management improvements.

Regarding its maintenance context, it is centralized and serves the entire plant. The internal maintenance team is reduced and the organization usually hires specialized and outsourced labor in major preventive interventions. Maintenance planning has the support of a known computerized maintenance management system (CMMS) to manage its activities. Due to the high availability demand of the generating units and short intervals for interventions, the prioritization of work orders to be carried out is essential. In addition, in cases of maintenance opportunities, knowing the most significant activities to be carried out keeps the maintenance execution in line with the needs and expectations of the maintenance management. 


\subsection{Selecting a Suitable MCMD Method}

In order to select a suitable MCDM method for the maintenance planning context of the organization, the proposed diagram was applied with support from the corporate maintenance and reliability engineer, the local engineer responsible for the operation and maintenance, and the local maintenance planning analyst. These professionals are directly involved in the hydroelectric power plant maintenance planning decision-making and this research project. The answers to the questions of the diagram are shown in Table 4 .

Table 4. Answers to the diagram considering the context of the case study hydroelectric plant.

\begin{tabular}{cll}
\hline$\#$ & Question & Answer \\
\hline 1 & $\begin{array}{l}\text { How are the criteria to be used in prioritizing work orders related } \\
\text { to each other? }\end{array}$ & The criteria are independent \\
\hline 2 & $\begin{array}{l}\text { How related is the information available on the work orders to } \\
\text { these prioritization criteria? }\end{array}$ & Highly related \\
\hline 3 & How long is the maintenance work order backlog? & - \\
\hline 4 & $\begin{array}{l}\text { Are the performance of the prioritization criteria offset against each } \\
\text { other? }\end{array}$ & Yes \\
\hline 5 & $\begin{array}{l}\text { What is the intended way to define the weights for the } \\
\text { prioritization criteria? }\end{array}$ & Systematic and participatory (with AHP) \\
\hline
\end{tabular}

Based on their answers, the final recommendation of the diagram led the decisionmakers to two options of hybrid methods: AHP-TOPSIS and AHP-VIKOR. The AHPTOPSIS option was selected for the case study because it combines two methods widely used in the MCDM literature. Furthermore, the Euclidean distance principle of TOPSIS was easier for participants to understand in the context of maintenance planning when compared to VIKOR. Therefore, the AHP was applied to obtain the relative weight of each criterion through the eigenvectors vector method of the pairwise comparison matrix. Then, this relative importance for the criteria was used as one of the inputs for the application of the TOPSIS method.

\subsection{Prioritizing Maintenance Work Orders}

The criteria used to prioritize maintenance work orders (MWO) and their relative weights are shown in Table 5. The criteria were defined in agreement with the maintenance leaders and their performance evaluations use the information available in the maintenance work orders in the CMMS.

Table 5. Criteria and relative weights for prioritizing MWO.

\begin{tabular}{clll}
\hline Weight & Criteria & Description & Performance \\
\hline 0.101 & $\begin{array}{l}\text { Maintenance work order cost } \\
\text { (MWOC) }\end{array}$ & $\begin{array}{l}\text { The total cost associated with the } \\
\text { maintenance order (spare parts, labor, } \\
\text { and logistics) }\end{array}$ & $\begin{array}{l}\text { Extremally high to } \\
\text { extremely low }\end{array}$ \\
\hline 0.607 & $\begin{array}{l}\text { Criticality of the associated } \\
\text { physical asset (CAPA) }\end{array}$ & $\begin{array}{l}\text { Score representing the degree of } \\
\text { criticality of the associated physical asset } \\
\text { in the service order }\end{array}$ & $\begin{array}{l}\text { Extremally high to } \\
\text { extremely low }\end{array}$ \\
\hline 0.243 & $\begin{array}{l}\text { Maintenance work order type } \\
\text { (MWOT) }\end{array}$ & $\begin{array}{l}\text { Classification of the maintenance service } \\
\text { order according to its type of priority }\end{array}$ & A score of work order type \\
\hline 0.048 & Waiting time (WT) & $\begin{array}{l}\text { Days since the maintenance work order } \\
\text { was opened in the CMMS for } \\
\text { maintenance planning }\end{array}$ & Number of waiting days \\
\hline
\end{tabular}


As previously discussed, the relative weights shown in Table 5 were obtained through an AHP application with support from maintenance leaders. First, these four prioritization criteria were pairwise compared to create the pairwise comparison matrix. This activity used the relative importance scale presented in Table 6 which was based on the fundamental scale of the AHP [66].

Table 6. Scale for pairwise comparison of criteria.

\begin{tabular}{cll}
\hline Score & Definition & Description \\
\hline 1 & Equal importance & $\begin{array}{l}\text { Two criteria contribute equally to the prioritization of } \\
\text { the MWO }\end{array}$ \\
\hline 3 & $\begin{array}{l}\text { Moderate } \\
\text { importance }\end{array}$ & $\begin{array}{l}\text { One criterion contributes slightly better to the } \\
\text { prioritization of the MWO over another }\end{array}$ \\
\hline 5 & Strong importance & $\begin{array}{l}\text { One criterion contributes strongly better to the } \\
\text { prioritization of the MWO over another }\end{array}$ \\
\hline 7 & $\begin{array}{l}\text { Very strong } \\
\text { importance }\end{array}$ & $\begin{array}{l}\text { One criterion contributes very strongly better to the } \\
\text { prioritization of the MWO over another }\end{array}$ \\
\hline 9 & $\begin{array}{l}\text { Extreme } \\
\text { importance }\end{array}$ & $\begin{array}{l}\text { One criterion contributes extremely better to the } \\
\text { prioritization of the MWO over another }\end{array}$ \\
\hline
\end{tabular}

The pairwise comparison matrix organized the relations of importance among the criteria after the judgments for prioritizing MWO, as shown in Table 7. For instance, the CAPA criterion is very strongly better for the prioritization of the MWO over the MWO criterion, as this comparison scored 7.

Table 7. Prioritization criteria pairwise comparison matrix.

\begin{tabular}{ccccc}
\hline & MWOC & CAPA & MWOT & WT \\
\hline MWOC & 1 & $1 / 7$ & $1 / 3$ & 3 \\
\hline CAPA & 7 & 1 & 3 & 9 \\
\hline MWOT & 3 & $1 / 3$ & 1 & 5 \\
\hline WT & $1 / 3$ & $1 / 9$ & $1 / 5$ & 1 \\
\hline
\end{tabular}

Then, from the pairwise comparison matrix presented in Table 7 , the criteria relative weights were obtained through the principal eigenvector of this matrix. For this, each element of the principal eigenvector of the pairwise comparison matrix was divided by the sum of its elements so that they sum to 1 [67], resulting in its corresponding relative weight. For instance, as MWOC is the first criterion in the pairwise comparison matrix, its relative weight was derived from the division of the first element in the principal eigenvector by the sum of its elements.

These prioritization criteria represent attributes of interest to achieve the objectives of maintenance planning. As can be seen in Table 5, the criticality of the associated physical asset is the criterion of greatest weight (0.607), followed by maintenance work order type (0.243), maintenance work order cost (0.101), and waiting time (0.048). The criticality criterion, specifically, is the result of a previous study that aggregates in an index several criteria related to different aspects of asset criticality such as reliability, maintainability, environmental classification, impact on availability, and others, according to the ISO 55000 series for asset management [68].

In this case study, the qualitative performance evaluation for MWOC, CAPA, and MWOT prioritization criteria was translated on a scale of 1 to 9 , where 1 is the lowest performance of the criterion and 9 is the highest, as shown in Table 8, with the support of the maintenance decision makers. This scale was not applied to the WT criterion since 
the information available in the CMMS to assess its performance is quantitative. Finally, it is worth mentioning the MWO prioritization of the case study aims to maximize the performance of CAPA, MWOT, and WT and, at the same time, minimize the MWOC.

Table 8. Conversion scale for qualitative evaluation of criteria performance.

\begin{tabular}{clll}
\hline Scale & MWOC & CAPA & MWOT \\
\hline 1 & Extremally low (EL) & Extremally low (EL) & Improvement (IP) \\
\hline 3 & Very low (VL) & Minor (MN) & Modification (MD) \\
\hline 5 & Moderate (MO) & Moderate (MO) & Corrective (CO) \\
\hline 7 & Very high (VH) & Major (MJ) & Predictive (PD) \\
\hline 9 & Extremally high (EH) & Extremally high (EH) & Preventive (PV) \\
\hline
\end{tabular}

The maintenance work orders database of this case study as well as the performance of these work orders in each of the criteria are presented in Appendix A (Table 1). This database was based on the actual information and context of the case study's hydroelectric power plant and limited the MWO to an adjacent generating unit and auxiliary equipment. Thus, a total of 71 MWOs were evaluated in each criterion.

In this study, the data values normalization procedure was performed by vector normalization, which is a standard technique used in the TOPSIS method $[19,61]$. The TOPSIS application followed the steps as presented in the literature [19,46,62,69-71]. Accordingly, these seven steps are briefly presented for better comprehension. Step 1 starts by establishing a decision matrix with the performance evaluations of $m$ alternatives across $n$ criteria as well as the weights of each decision criteria, as exemplified in Table 9.

Table 9. Matrix of decision example for TOPSIS application.

\begin{tabular}{ccccc}
\hline Objective & $\begin{array}{c}\text { Max. or Min. } \\
\text { Criterion 1 }\end{array}$ & $\begin{array}{c}\text { Max. or Min. } \\
\text { Criterion 2 }\end{array}$ & $\ldots$ & $\begin{array}{c}\text { Max. or Min. } \\
\text { Criterion } \mathbf{n}\end{array}$ \\
\hline Alternative 1 & $\mathrm{x}_{11}$ & $\mathrm{x}_{12}$ & $\ldots$ & $\mathrm{x}_{1 \mathrm{n}}$ \\
Alternative 2 & $\mathrm{x}_{21}$ & $\mathrm{x}_{22}$ & $\ldots$ & $\mathrm{x}_{2 \mathrm{n}}$ \\
Alternative 3 & $\mathrm{x}_{31}$ & $\mathrm{x}_{32}$ & $\ldots$ & $\mathrm{x}_{3 \mathrm{n}}$ \\
$\ldots$ & $\ldots$ & $\ldots$ & $\ldots$ & $\ldots$ \\
Alternative $\mathrm{m}$ & $\mathrm{x}_{\mathrm{m} 1}$ & $\mathrm{x}_{\mathrm{m} 2}$ & $\ldots$ & $\mathrm{x}_{\mathrm{mn}}$ \\
\hline $\mathrm{w}_{\mathrm{j}}$ (weight) & $\mathrm{w}_{1}$ & $\mathrm{w}_{2}$ & $\ldots$ & $\mathrm{w}_{\mathrm{n}}$ \\
\hline
\end{tabular}

In Step 2, TOPSIS applies the vector normalization (Equation (1)) to normalize the decision matrix values, where $r_{i j}=$ normalized value and $x_{i j}$ is the performance value of the alternative $i$ for the criterion $j$.

$$
r_{i j}=\frac{x_{i j}}{\sqrt{\sum_{i=1}^{m} x_{i j}^{2}}}, i=1,2, \ldots, m, \quad j=1,2, \ldots, n
$$

Then, Step 3 creates the weighted normalized matrix by multiplying the weight of each decision criterion $\left(w_{j}\right)$ for each normalized value of the matrix, as presented in Equation (2).

$$
V_{i j}=w_{j} * r_{i j}, \quad i=1,2, \ldots, m, \quad j=1,2, \ldots, n
$$

In Step 4, TOPSIS computes the positive ideal solution (PIS) and negative ideal solution (NIS) through Equations (3) and (4). Then, it obtains the distance of each alternative from PIS and NIS in Step 5. These distances (separation measure for alternatives using n-dimensional Euclidean distance) are calculated using Equations (5) and (6). 


$$
\begin{gathered}
\text { PIS }=\left\{v_{1}^{+}, v_{2}^{+}, \ldots, v_{n}^{+}\right\}, \quad v_{j}^{+}=\left\{\max \left(v_{i j}\right), \quad i=1,2, \ldots, m\right\} \\
\text { NIS }=\left\{v_{1}^{-}, v_{2}^{-}, \ldots, v_{n}^{-}\right\}, \quad v_{j}^{-}=\left\{\min \left(v_{i j}\right), \quad i=1,2, \ldots, m\right\} \\
S_{i}^{+}=\sqrt{\sum_{j=1}^{n}\left(v_{i j}-v_{j}^{+}\right)^{2}}, \quad i=1,2, \ldots, m \\
S_{i}^{-}=\sqrt{\sum_{j=1}^{n}\left(v_{i j}-v_{j}^{-}\right)^{2}}, \quad i=1,2, \ldots, m
\end{gathered}
$$

In Step 6, TOPSIS calculates the closeness coefficient $\left(C C_{i}\right)$, also known as the performance score $\left(\mathrm{P}_{\mathrm{i}}\right)$, for each alternative using its distances to the ideal solution and the worst solution, as shown in Equation (7). Finally, Step 7 ranks the alternatives according to the descending order of $\mathrm{CC} i$, determining which is the best alternative based on which has the highest closeness coefficient.

$$
C C_{i}=s_{i}^{-} /\left(s_{i}^{*}+s_{i}^{-}\right), \quad i=1,2, \ldots, m
$$

The maximum $C C_{i}$ is 1 and is only obtained when an alternative has the best performance for all criteria. On the other hand, if an alternative has the worst performance in each criterion, it will have a $C C_{i}$ equal to $0[19,60]$. In this case study, the final classification for maintenance work order prioritization is determined by the ranking of the $C_{i}$ indicator.

\begin{tabular}{|c|c|c|c|c|}
\hline MWO & Description & Location & $C C_{i}$ & Rank \\
\hline 0018425 & $\begin{array}{l}\text { Analysis of the lubricating oil of the combined generator } \\
\text { bearing }\end{array}$ & Generating unit 01 & 0.914875 & 1 \\
\hline 0018843 & $\begin{array}{l}\text { Lubricating oil filtration of the combined generator bearing } \\
\text { reservoir }\end{array}$ & Generating unit 01 & 0.912172 & 2 \\
\hline 0021589 & Electrical inspection of turbine guide motor pumps & Generating unit 01 & 0.897340 & 3 \\
\hline 0021783 & Electrical inspection of water intake grills cleaner & Generating unit 01 & 0.894533 & 4 \\
\hline 0021925 & Analysis of the lubricating oil of the guide turbine bearing & Generating unit 01 & 0.893576 & 5 \\
\hline 0022011 & Electrical inspection of the Step-up transformer 7TR1 & Generating unit 01 & 0.890321 & 6 \\
\hline 0022784 & Lubrication of water intake grills cleaner elements & Generating unit 01 & 0.887751 & 7 \\
\hline 0024762 & Cleaning and adjustment of inductive water intake gate 02 & Generating unit 01 & 0.886996 & 8 \\
\hline 0023094 & Lubricate the bearings of the hydrant pump & Auxiliary equipment & 0.884327 & 9 \\
\hline 0023261 & $\begin{array}{l}\text { Perform vibration analysis on combined generator bearing } \\
\text { motor pump }\end{array}$ & Generating unit 01 & 0.880757 & 10 \\
\hline$\cdots$ & $\cdots$ & $\ldots$ & $\ldots$ & $\ldots$ \\
\hline 0025562 & Electrical inspection of downstream lifting gantry & Auxiliary equipment & 0.382283 & 66 \\
\hline 0018037 & Replace the spillway lifting gantry cable & Auxiliary equipment & 0.377074 & 67 \\
\hline 0021158 & Replacement of transmission belts of exhaust fan 01 & Auxiliary equipment & 0.303835 & 68 \\
\hline 0022681 & Exhaust fan 02 rotor balancing & Auxiliary equipment & 0.300278 & 69 \\
\hline 0019963 & $\begin{array}{l}\text { Perform vibration analysis on exhaust fan of battery bank } \\
\text { room }\end{array}$ & Auxiliary equipment & 0.293832 & 70 \\
\hline 0025749 & Adjust position of the downstream surveillance camera & Auxiliary equipment & 0.250726 & 71 \\
\hline
\end{tabular}
Table 10 presents the maintenance work orders prioritized after the application of TOPSIS, where the topmost priority work orders can be observed as well as the lowest priority maintenance work orders.

Table 10. Ranked maintenance work orders after the TOPSIS application. 
As can be seen in Table 10, the application was able to identify the topmost priority maintenance work orders among the MWO database. The first $10 \mathrm{MWO}$ of the prioritization are all associated with highly critical physical assets for the hydroelectric power plant. This is consistent with the preferences of the decision makers, as the weights obtained for the criteria with the application of the AHP resulted in CAPA being the most relevant criterion. Moreover, the highest priority maintenance work orders are all preventive or predictive, which contributes to high performance in the second-most important criterion for this application (MWOT). Lastly, these MWOs are low- or extremely low-cost and almost all have been awaiting execution for more than 90 days.

The five lowest priority maintenance work orders are associated with extremely low or minor criticality. Although these MWOs are mostly of the preventive type and have been awaiting execution for a long time, they were at the bottom of the ranking, indicating that there were more pertinent maintenance work orders to be executed first, especially due to the criticality of the associated physical assets. Furthermore, these lowest priority MWOs performed worse on average than the topmost priority orders regarding maintenance cost.

Accordingly, the recommended hybrid AHP-TOPSIS MCDM method application was able to identify the topmost and the lowest priority MWOs among the maintenance work order database. This corroborates the importance of an aided decision-making process since prioritizing the MWO without the support of an MCDM method would not be a simple and promising activity.

\section{Discussion}

In addition to demonstrating the proposed method for a real context of maintenance planning in a hydroelectric power plant, this case study also contributes to the discussion of the novelties of the method in relation to the studies identified in the literature. First, the proposed method considered eight MCDM methods in the elaboration of its decision tree diagram that recommends the most appropriate MCDM method for the maintenance planning context of an organization. Although there are other MCDM methods that were not considered in the proposed diagram, it is still more comprehensive than previous works that also developed decision flowcharts, as they considered fewer methods in their approaches $[46,56]$.

The transparency of the proposed method is another important point to be mentioned. In other words, the user can identify the recommendations of the MCDM method from other sets of input answers rather than those in this particular case study. For instance, this is not possible in a software interface approach such as that presented by Haddad et al., since it only presents the MCDM method recommendations for a particular case [54,57]. This transparency is essential for other researchers and professionals to use and adapt the proposed method in different contexts.

Moreover, the proposed method also stands out for presenting a decision tree diagram in a language accessible and translated to the maintenance planning context. Unlike other methods in the literature $[46,54,56,57]$, it does not require decision-makers to have prior and specialized knowledge about the characteristics of MCDM methods. This also contributes to the usability of the method even more in an area that is not so familiar with applications of methods to support decision-making. Nevertheless, before applying the recommended method, the user shall be familiar with the MCDM method and be able to understand how it works and the interpretation of its results for the maintenance planning context.

Finally, it is worth mentioning that the proposed method does not consider the uncertainty of the decision makers' responses when applying the method. Similar to other approaches identified in the literature $[46,54,56,57]$, a wrong answer in the proposed diagram can influence the final recommendation of the MCDM method. Nevertheless, if the uncertainty is in the data referring to the performance evaluation of the maintenance work orders, the proposed method suggests that the user evaluate the incorporation of techniques that deal with uncertainty, such as the fuzzy theory in the application. 


\section{Conclusions}

Since decision-making has begun to become more complex, simple heuristics are not enough to point out the best solutions. MCDM methods have been widely used by professionals and researchers for this purpose in the last decades. Nevertheless, the approaches to support the selection of an MCDM method are still lacking in the literature. Moreover, although many MCDM methods have been applied to solve problems in various fields, maintenance management applications are scarce despite the challenges and their importance to industrial activities. In this context, this paper proposed a novel knowledgebased method for deciding a multicriteria decision-making (MCDM) method to prioritize maintenance work orders of hydroelectric power plants based on a decision tree diagram.

Therefore, this paper contributes to the research fields of decision-making in maintenance management in several aspects. It provides an overview of the strengths and weaknesses of the main MCDM methods in the literature. Second, it proposes a novel knowledge-based diagram for deciding an MCDM method to prioritize maintenance work orders. It also addresses the intrinsic characteristics of the methods in a language accessible to maintenance planning. Finally, it demonstrates the proposed method with a case study that contributes to the understanding and dissemination of the potential for using MCDM methods in maintenance planning. Accordingly, it is expected that these findings will be of aid to researchers and practitioners in the maintenance field in improving maintenance planning decision-making.

As opportunities for future work, the authors suggest analyzing the maintenance work orders database to determine the best normalization technique and comparing the impact on the prioritization with the previous prioritization determined by using the intrinsic normalization technique of the TOPSIS method. As the literature lacks studies related to maintenance management decision-making, the authors also suggest exploring and developing methods that can be applied to other maintenance processes and activities besides maintenance planning in order to contribute to the achievement of the asset management objectives of hydroelectric power plants. Finally, the adaptation or generalization of the proposed method to cover other contexts besides maintenance management are also suggestions for future works.

Author Contributions: Conceptualization, R.F.d.S., M.M.B., S.A. and F.E.C.; methodology, R.F.d.S., M.M.B., S.A., F.E.C., G.F.M.d.S. and M.B.; formal analysis, R.F.d.S., M.M.B., S.A. and F.E.C.; investigation, R.F.d.S., M.M.B., S.A., F.E.C., G.F.M.d.S. and M.B.; resources, G.F.M.d.S. and M.B.; data curation, R.F.d.S., M.M.B. and G.F.M.d.S.; writing-original draft preparation, R.F.d.S. and M.M.B.; writing—review and editing, R.F.d.S., M.M.B., S.A., F.E.C., G.F.M.d.S. and M.B.; validation, R.F.d.S and M.M.B.; supervision, G.F.M.d.S. and M.B.; funding acquisition, G.F.M.d.S. All authors have read and agreed to the published version of the manuscript.

Funding: This research received no external funding.

Acknowledgments: G.F.M.d.S. and R.F.d.S. gratefully acknowledge the financial support provided by Fundação para o Desenvolvimento Tecnológico da Engenharia (FDTE) and Energia de Portugal (EDP), through an ANEEL R\&D project, for the development of the present research.

Conflicts of Interest: The authors declare no conflict of interest.

\section{Appendix A}

Table 1. Database of maintenance work orders (MWO) and their performance in each criterion.

\begin{tabular}{|c|c|c|c|c|c|c|c|}
\hline MWO & Description & Location & System & MWOC & CAPA & MWOT & WT \\
\hline 0018037 & $\begin{array}{l}\text { Replace the spillway lifting gantry } \\
\text { cable }\end{array}$ & $\begin{array}{l}\text { Auxiliary } \\
\text { equipment }\end{array}$ & Lifting Equipment & $\mathrm{VH}$ & $\mathrm{MN}$ & PV & 257 \\
\hline 0018102 & $\begin{array}{l}\text { External triennial inspection of the } \\
\text { air-oil hydraulic accumulator }\end{array}$ & $\begin{array}{l}\text { Generating } \\
\text { unit } 01\end{array}$ & $\begin{array}{l}\text { Speed governor } \\
\text { system }\end{array}$ & VL & MJ & PD & 232 \\
\hline
\end{tabular}


Table 1. Cont.

\begin{tabular}{|c|c|c|c|c|c|c|c|}
\hline MWO & Description & Location & System & MWOC & CAPA & MWOT & WT \\
\hline 0018163 & $\begin{array}{l}\text { Lubrication of upstream lifting } \\
\text { gantry elements }\end{array}$ & $\begin{array}{l}\text { Auxiliary } \\
\text { equipment }\end{array}$ & Lifting Equipment & VL & $\mathrm{MN}$ & PV & 223 \\
\hline 0018186 & $\begin{array}{l}\text { Replacement of corroded parts of the } \\
\text { water intake grill }\end{array}$ & $\begin{array}{l}\text { Generating } \\
\text { unit } 01\end{array}$ & Water intake & $\mathrm{VH}$ & $\mathrm{EH}$ & $\mathrm{CO}$ & 216 \\
\hline 0018223 & $\begin{array}{l}\text { External triennial inspection of the } \\
\text { compressed air receiver }\end{array}$ & $\begin{array}{l}\text { Auxiliary } \\
\text { equipment }\end{array}$ & Compressed air & VL & MJ & PD & 213 \\
\hline 0018425 & $\begin{array}{l}\text { Analysis of the lubricating oil of the } \\
\text { combined generator bearing }\end{array}$ & $\begin{array}{l}\text { Generating } \\
\text { unit } 01\end{array}$ & Bearings & EL & $\mathrm{EH}$ & PD & 207 \\
\hline 0018656 & $\begin{array}{l}\text { Calibration of compressed air } \\
\text { receiver pressure gauge }\end{array}$ & $\begin{array}{l}\text { Auxiliary } \\
\text { equipment }\end{array}$ & Compressed air & VL & MJ & PV & 198 \\
\hline 0018834 & $\begin{array}{l}\text { Electrical inspection of self-cleaning } \\
\text { filter system }\end{array}$ & $\begin{array}{l}\text { Generating } \\
\text { unit } 01\end{array}$ & $\begin{array}{l}\text { Water circulation } \\
\text { system }\end{array}$ & EL & $\mathrm{MN}$ & PD & 187 \\
\hline 0018843 & $\begin{array}{l}\text { Lubricating oil filtration of the } \\
\text { combined generator bearing reservoir }\end{array}$ & $\begin{array}{l}\text { Generating } \\
\text { unit } 01\end{array}$ & Bearings & VL & $\mathrm{EH}$ & PV & 187 \\
\hline 0019862 & $\begin{array}{l}\text { Fix air leakage from the compressor } \\
\text { breather on compressor number } 1 \text { of } \\
64 \text { bar }\end{array}$ & $\begin{array}{l}\text { Auxiliary } \\
\text { equipment }\end{array}$ & Compressed air & VL & MJ & $\mathrm{CO}$ & 169 \\
\hline 0019963 & $\begin{array}{l}\text { Perform vibration analysis on } \\
\text { exhaust fan of battery bank room }\end{array}$ & $\begin{array}{l}\text { Auxiliary } \\
\text { equipment }\end{array}$ & $\begin{array}{l}\text { Exhaust and } \\
\text { ventilation systems }\end{array}$ & EL & EL & PD & 166 \\
\hline 0020396 & $\begin{array}{l}\text { Level sensor adjustment of turbine } \\
\text { cover }\end{array}$ & $\begin{array}{l}\text { Generating } \\
\text { unit } 01\end{array}$ & Turbine & EL & $\mathrm{EH}$ & $\mathrm{CO}$ & 159 \\
\hline 0021158 & $\begin{array}{l}\text { Replacement of transmission belts of } \\
\text { exhaust fan } 01\end{array}$ & $\begin{array}{l}\text { Auxiliary } \\
\text { equipment }\end{array}$ & $\begin{array}{l}\text { Exhaust and } \\
\text { ventilation systems }\end{array}$ & VL & EL & PV & 156 \\
\hline 0021245 & $\begin{array}{l}\text { Chromatographic analysis of the } \\
\text { insulating oil }\end{array}$ & $\begin{array}{l}\text { Generating } \\
\text { unit } 01\end{array}$ & $\begin{array}{l}\text { Step up } \\
\text { transformer 7TR1 }\end{array}$ & VL & $\mathrm{EH}$ & PD & 153 \\
\hline 0021269 & $\begin{array}{l}\text { Internal triennial inspection of the } \\
\text { compressed air receiver } 25 \text { bar }\end{array}$ & $\begin{array}{l}\text { Auxiliary } \\
\text { equipment }\end{array}$ & Compressed air & $\mathrm{MO}$ & MJ & PD & 150 \\
\hline 0021526 & $\begin{array}{l}\text { Analysis of the lubricating oil of the } \\
\text { speed governor system }\end{array}$ & $\begin{array}{l}\text { Generating } \\
\text { unit } 01\end{array}$ & $\begin{array}{l}\text { Speed governor } \\
\text { system }\end{array}$ & EL & MJ & PD & 146 \\
\hline 0021589 & $\begin{array}{l}\text { Electrical inspection of turbine guide } \\
\text { motor pumps }\end{array}$ & $\begin{array}{l}\text { Generating } \\
\text { unit } 01\end{array}$ & Bearings & EL & $\mathrm{EH}$ & PD & 135 \\
\hline 0021783 & $\begin{array}{l}\text { Electrical inspection of water intake } \\
\text { grills cleaner }\end{array}$ & $\begin{array}{l}\text { Generating } \\
\text { unit } 01\end{array}$ & Water intake & EL & $\mathrm{EH}$ & PD & 126 \\
\hline 0021925 & $\begin{array}{l}\text { Analysis of the lubricating oil of the } \\
\text { guide turbine bearing }\end{array}$ & $\begin{array}{l}\text { Generating } \\
\text { unit } 01\end{array}$ & Bearings & EL & $\mathrm{EH}$ & PD & 123 \\
\hline 0021940 & $\begin{array}{l}\text { Change the compressor lubricating } \\
\text { oil of compressor number } 1 \text { of } 8 \text { bar }\end{array}$ & $\begin{array}{l}\text { Auxiliary } \\
\text { equipment }\end{array}$ & Compressed air & $\mathrm{MO}$ & MJ & PV & 120 \\
\hline 0021963 & $\begin{array}{l}\text { Cleaning of the electrical panels of } \\
\text { the lifting equipment }\end{array}$ & $\begin{array}{l}\text { Auxiliary } \\
\text { equipment }\end{array}$ & Lifting Equipment & EL & $\mathrm{MN}$ & PV & 120 \\
\hline 0022011 & $\begin{array}{l}\text { Electrical inspection of the Step-up } \\
\text { transformer 7TR1 }\end{array}$ & $\begin{array}{l}\text { Generating } \\
\text { unit } 01\end{array}$ & $\begin{array}{l}\text { Step up } \\
\text { transformer 7TR1 }\end{array}$ & EL & $\mathrm{EH}$ & PD & 113 \\
\hline 0022141 & $\begin{array}{l}\text { Fix the leakage in the water intake } \\
\text { grills cleaner hydraulic unit }\end{array}$ & $\begin{array}{l}\text { Generating } \\
\text { unit } 01\end{array}$ & Water intake & $\mathrm{MO}$ & $\mathrm{EH}$ & $\mathrm{CO}$ & 112 \\
\hline 0022229 & $\begin{array}{l}\text { Electrical inspection of motorized } \\
\text { valve } 8\end{array}$ & $\begin{array}{l}\text { Generating } \\
\text { unit } 01\end{array}$ & $\begin{array}{l}\text { Water circulation } \\
\text { system }\end{array}$ & EL & $\mathrm{MN}$ & PV & 111 \\
\hline 0022239 & $\begin{array}{l}\text { Perform vibration analysis on speed } \\
\text { governor motor pump } 2\end{array}$ & $\begin{array}{l}\text { Generating } \\
\text { unit } 01\end{array}$ & $\begin{array}{l}\text { Speed governor } \\
\text { system }\end{array}$ & EL & MJ & PD & 111 \\
\hline
\end{tabular}


Table 1. Cont.

\begin{tabular}{|c|c|c|c|c|c|c|c|}
\hline MWO & Description & Location & System & MWOC & CAPA & MWOT & WT \\
\hline 0022241 & $\begin{array}{l}\text { Electrical inspection of speed } \\
\text { governor motor pump } 2\end{array}$ & $\begin{array}{l}\text { Generating } \\
\text { unit } 01\end{array}$ & $\begin{array}{l}\text { Speed governor } \\
\text { system }\end{array}$ & EL & MJ & PD & 111 \\
\hline 0022251 & $\begin{array}{l}\text { Cleaning of the excitation system } \\
\text { elements }\end{array}$ & $\begin{array}{l}\text { Generating } \\
\text { unit } 01\end{array}$ & Excitation system & EL & MJ & PV & 111 \\
\hline 0022335 & $\begin{array}{l}\text { Replacement of the combined bearing } \\
\text { temperature sensor } 4\end{array}$ & $\begin{array}{l}\text { Generating } \\
\text { unit } 01\end{array}$ & Bearings & VL & $\mathrm{EH}$ & $\mathrm{CO}$ & 109 \\
\hline 0022489 & $\begin{array}{l}\text { Fix the leakage in the speed governor } \\
\text { hydraulic unit }\end{array}$ & $\begin{array}{l}\text { Generating } \\
\text { unit } 01\end{array}$ & $\begin{array}{l}\text { Speed governor } \\
\text { system }\end{array}$ & $\mathrm{MO}$ & MJ & $\mathrm{CO}$ & 106 \\
\hline 0022681 & Exhaust fan 02 rotor balancing & $\begin{array}{l}\text { Auxiliary } \\
\text { equipment }\end{array}$ & $\begin{array}{l}\text { Exhaust and } \\
\text { ventilation systems }\end{array}$ & VL & EL & PV & 104 \\
\hline 0022784 & $\begin{array}{l}\text { Lubrication of water intake grills } \\
\text { cleaner elements }\end{array}$ & $\begin{array}{l}\text { Generating } \\
\text { unit } 01\end{array}$ & Water intake & VL & $\mathrm{EH}$ & PV & 102 \\
\hline 0022855 & $\begin{array}{l}\text { Calibration of air-oil hydraulic } \\
\text { accumulator pressure gauge }\end{array}$ & $\begin{array}{l}\text { Generating } \\
\text { unit } 01\end{array}$ & $\begin{array}{l}\text { Speed governor } \\
\text { system }\end{array}$ & VL & MJ & PV & 98 \\
\hline 0023094 & $\begin{array}{l}\text { Lubricate the bearings of the hydrant } \\
\text { pump }\end{array}$ & $\begin{array}{l}\text { Auxiliary } \\
\text { equipment }\end{array}$ & Firefighting system & VL & $\mathrm{EH}$ & PV & 92 \\
\hline 0023231 & $\begin{array}{l}\text { Fix water leakage in the heat } \\
\text { exchanger of guide turbine bearing }\end{array}$ & $\begin{array}{l}\text { Generating } \\
\text { unit } 01\end{array}$ & Bearings & VL & $\mathrm{EH}$ & $\mathrm{CO}$ & 87 \\
\hline 0023261 & $\begin{array}{l}\text { Perform vibration analysis on } \\
\text { combined generator bearing motor } \\
\text { pump }\end{array}$ & $\begin{array}{l}\text { Generating } \\
\text { unit } 01\end{array}$ & Bearings & EL & $\mathrm{EH}$ & PD & 85 \\
\hline 0023346 & $\begin{array}{l}\text { Annual preventive maintenance on } \\
\text { compressor number } 1 \text { of } 64 \text { bar }\end{array}$ & $\begin{array}{l}\text { Auxiliary } \\
\text { equipment }\end{array}$ & Compressed air & $\mathrm{MO}$ & MJ & PV & 79 \\
\hline 0023357 & $\begin{array}{l}\text { Annual preventive maintenance on } \\
\text { compressor number } 2 \text { of } 64 \text { bar }\end{array}$ & $\begin{array}{l}\text { Auxiliary } \\
\text { equipment }\end{array}$ & Compressed air & $\mathrm{MO}$ & MJ & PV & 79 \\
\hline 0023582 & $\begin{array}{l}\text { Perform motor circuit analysis on } \\
\text { combined bearing motor pumps }\end{array}$ & $\begin{array}{l}\text { Generating } \\
\text { unit } 01\end{array}$ & Bearings & VL & $\mathrm{EH}$ & PD & 75 \\
\hline 0024023 & $\begin{array}{l}\text { Thermographic analysis on the } \\
\text { panels and relays of turbine }\end{array}$ & $\begin{array}{l}\text { Generating } \\
\text { unit } 01\end{array}$ & $\begin{array}{l}\text { Control and } \\
\text { automation }\end{array}$ & EL & $\mathrm{MN}$ & PD & 65 \\
\hline 0024051 & $\begin{array}{l}\text { Thermographic analysis on the } \\
\text { panels and relays of generator }\end{array}$ & $\begin{array}{l}\text { Generating } \\
\text { unit } 01\end{array}$ & $\begin{array}{l}\text { Control and } \\
\text { automation }\end{array}$ & EL & $\mathrm{MN}$ & PD & 65 \\
\hline 0024160 & $\begin{array}{l}\text { Perform motor circuit analysis on } \\
\text { speed governor motor pump } 1\end{array}$ & $\begin{array}{l}\text { Generating } \\
\text { unit } 01\end{array}$ & $\begin{array}{l}\text { Speed governor } \\
\text { system }\end{array}$ & VL & MJ & PV & 64 \\
\hline 0024241 & $\begin{array}{l}\text { Fix the oil leakage in the combine } \\
\text { generator bearing }\end{array}$ & $\begin{array}{l}\text { Generating } \\
\text { unit } 01\end{array}$ & Bearings & $\mathrm{MO}$ & MJ & $\mathrm{CO}$ & 62 \\
\hline 0024283 & $\begin{array}{l}\text { Replace temperature sensor } 3 \text { of } \\
\text { excitation system }\end{array}$ & $\begin{array}{l}\text { Generating } \\
\text { unit } 01\end{array}$ & Excitation system & VL & MJ & $\mathrm{CO}$ & 60 \\
\hline 0024349 & $\begin{array}{l}\text { Electrical inspection of overhead } \\
\text { crane }\end{array}$ & $\begin{array}{l}\text { Auxiliary } \\
\text { equipment }\end{array}$ & Lifting Equipment & EL & MJ & PD & 56 \\
\hline 0024386 & $\begin{array}{l}\text { Change bearings on motor pump } 2 \text { of } \\
\text { combine generator bearings }\end{array}$ & $\begin{array}{l}\text { Generating } \\
\text { unit } 01\end{array}$ & Bearings & $\mathrm{MO}$ & $\mathrm{EH}$ & $\mathrm{CO}$ & 56 \\
\hline 0024440 & $\begin{array}{l}\text { Electrical inspection of compressor } \\
\text { number } 1 \text { of } 25 \text { bar }\end{array}$ & $\begin{array}{l}\text { Auxiliary } \\
\text { equipment }\end{array}$ & Compressed air & EL & MJ & PD & 50 \\
\hline 0024581 & $\begin{array}{l}\text { Annual preventive maintenance on } \\
\text { compressor number } 1 \text { of } 8 \text { bar }\end{array}$ & $\begin{array}{l}\text { Auxiliary } \\
\text { equipment }\end{array}$ & Compressed air & $\mathrm{MO}$ & MJ & PV & 43 \\
\hline 0024648 & $\begin{array}{l}\text { Preventive maintenance in the gasket } \\
\text { box of turbine cover }\end{array}$ & $\begin{array}{l}\text { Generating } \\
\text { unit } 01\end{array}$ & Turbine & VL & $\mathrm{EH}$ & PV & 43 \\
\hline
\end{tabular}


Table 1. Cont.

\begin{tabular}{|c|c|c|c|c|c|c|c|}
\hline MWO & Description & Location & System & MWOC & CAPA & MWOT & WT \\
\hline 0024649 & $\begin{array}{l}\text { Electrical inspection of turbine cover } \\
\text { motor pump } 1\end{array}$ & $\begin{array}{l}\text { Generating } \\
\text { unit } 01\end{array}$ & Turbine & EL & $\mathrm{EH}$ & PD & 43 \\
\hline 0024681 & $\begin{array}{l}\text { Modify position of speed governor } \\
\text { motor pump } 2\end{array}$ & $\begin{array}{l}\text { Generating } \\
\text { unit } 01\end{array}$ & $\begin{array}{l}\text { Speed governor } \\
\text { system }\end{array}$ & VL & MJ & MD & 39 \\
\hline 0024753 & $\begin{array}{l}\text { Thermographic analysis of the } \\
\text { Step-up transformer 7TR1 }\end{array}$ & $\begin{array}{l}\text { Generating } \\
\text { unit } 01\end{array}$ & $\begin{array}{l}\text { Step up } \\
\text { transformer 7TR1 }\end{array}$ & EL & $\mathrm{EH}$ & PD & 38 \\
\hline 0024762 & $\begin{array}{l}\text { Cleaning and adjustment of inductive } \\
\text { water intake gate } 02\end{array}$ & $\begin{array}{l}\text { Generating } \\
\text { unit } 01\end{array}$ & Water intake & EL & $\mathrm{EH}$ & PV & 37 \\
\hline 0024810 & $\begin{array}{l}\text { Cleaning the electrical panels of } \\
\text { water intake gates }\end{array}$ & $\begin{array}{l}\text { Generating } \\
\text { unit } 01\end{array}$ & Water intake & EL & $\mathrm{MN}$ & PV & 37 \\
\hline 0024920 & $\begin{array}{l}\text { Lubrication of overhead crane } \\
\text { elements }\end{array}$ & $\begin{array}{l}\text { Auxiliary } \\
\text { equipment }\end{array}$ & Lifting Equipment & VL & MJ & PV & 36 \\
\hline 0025128 & $\begin{array}{l}\text { Inspection of the hydraulic actuation } \\
\text { system of the water intake gate } 01\end{array}$ & $\begin{array}{l}\text { Generating } \\
\text { unit } 01\end{array}$ & Water intake & EL & $\mathrm{EH}$ & PD & 34 \\
\hline 0025136 & $\begin{array}{l}\text { Change the lubricating oil of the } \\
\text { hydraulic unit }\end{array}$ & $\begin{array}{l}\text { Generating } \\
\text { unit } 01\end{array}$ & Water intake & $\mathrm{MO}$ & $\mathrm{EH}$ & PV & 34 \\
\hline 0025138 & $\begin{array}{l}\text { Inspection of the hydraulic actuation } \\
\text { system of the water intake gate } 02\end{array}$ & $\begin{array}{l}\text { Generating } \\
\text { unit } 01\end{array}$ & Water intake & EL & $\mathrm{EH}$ & PD & 34 \\
\hline 0025209 & $\begin{array}{l}\text { Inspection of the hydraulic actuation } \\
\text { system of the water intake gate } 03\end{array}$ & $\begin{array}{l}\text { Generating } \\
\text { unit } 01\end{array}$ & Water intake & EL & $\mathrm{EH}$ & PD & 34 \\
\hline 0025248 & $\begin{array}{l}\text { Perform motor circuit analysis on } \\
\text { guide bearing motor pumps }\end{array}$ & $\begin{array}{l}\text { Generating } \\
\text { unit } 01\end{array}$ & Bearings & VL & $\mathrm{EH}$ & PD & 33 \\
\hline 0025259 & $\begin{array}{l}\text { Electrical inspection of excitation } \\
\text { system }\end{array}$ & $\begin{array}{l}\text { Generating } \\
\text { unit } 01\end{array}$ & Excitation system & EL & $\mathrm{MN}$ & PD & 33 \\
\hline 0025562 & $\begin{array}{l}\text { Electrical inspection of downstream } \\
\text { lifting gantry }\end{array}$ & $\begin{array}{l}\text { Auxiliary } \\
\text { equipment }\end{array}$ & Lifting Equipment & EL & $\mathrm{MN}$ & PD & 28 \\
\hline 0025651 & $\begin{array}{l}\text { Cleaning the electrical panels of } \\
\text { turbine }\end{array}$ & $\begin{array}{l}\text { Generating } \\
\text { unit } 01\end{array}$ & $\begin{array}{l}\text { Control and } \\
\text { automation }\end{array}$ & EL & $\mathrm{MN}$ & PV & 24 \\
\hline 0025669 & $\begin{array}{l}\text { Electrical insulation tests of the rotor } \\
\text { and stator }\end{array}$ & $\begin{array}{l}\text { Generating } \\
\text { unit } 01\end{array}$ & Generator & $\mathrm{MO}$ & MJ & PV & 24 \\
\hline 0025749 & $\begin{array}{l}\text { Adjust position of the downstream } \\
\text { surveillance camera }\end{array}$ & $\begin{array}{l}\text { Auxiliary } \\
\text { equipment }\end{array}$ & $\begin{array}{l}\text { Vigilance camera } \\
\text { system }\end{array}$ & EL & EL & $\mathrm{CO}$ & 22 \\
\hline 0025779 & Hydraulic unit oil filtration & $\begin{array}{l}\text { Generating } \\
\text { unit } 01\end{array}$ & $\begin{array}{l}\text { Speed governor } \\
\text { system }\end{array}$ & VL & MJ & PV & 20 \\
\hline 0025841 & $\begin{array}{l}\text { Cleaning the electrical panels of } \\
\text { speed governor }\end{array}$ & $\begin{array}{l}\text { Generating } \\
\text { unit } 01\end{array}$ & $\begin{array}{l}\text { Control and } \\
\text { automation }\end{array}$ & EL & $\mathrm{MN}$ & PV & 14 \\
\hline 0025950 & $\begin{array}{l}\text { Install online filtration system for } \\
\text { lubricating oil }\end{array}$ & $\begin{array}{l}\text { Generating } \\
\text { unit } 01\end{array}$ & $\begin{array}{l}\text { Speed governor } \\
\text { system }\end{array}$ & $\mathrm{VH}$ & $\mathrm{EH}$ & IP & 9 \\
\hline 0025980 & $\begin{array}{l}\text { Retighten circuit breaker connections } \\
\text { on the speed governor panel }\end{array}$ & $\begin{array}{l}\text { Generating } \\
\text { unit } 01\end{array}$ & $\begin{array}{l}\text { Speed governor } \\
\text { system }\end{array}$ & EL & $\mathrm{MN}$ & PV & 9 \\
\hline 0026005 & $\begin{array}{l}\text { Electrical inspection of compressor } \\
\text { number } 1 \text { of } 64 \text { bar }\end{array}$ & $\begin{array}{l}\text { Auxiliary } \\
\text { equipment }\end{array}$ & Compressed air & EL & MJ & PD & 7 \\
\hline 0026091 & $\begin{array}{l}\text { Installation of an accelerometer for } \\
\text { collecting vibration on the motor } \\
\text { pumps }\end{array}$ & $\begin{array}{l}\text { Generating } \\
\text { unit } 01\end{array}$ & Bearings & $\mathrm{MO}$ & $\mathrm{EH}$ & IP & 7 \\
\hline 0026149 & $\begin{array}{l}\text { Change bearings on motor pump } 1 \text { of } \\
\text { speed governor system }\end{array}$ & $\begin{array}{l}\text { Generating } \\
\text { unit } 01\end{array}$ & $\begin{array}{l}\text { Speed governor } \\
\text { system }\end{array}$ & $\mathrm{MO}$ & MJ & PV & 4 \\
\hline
\end{tabular}




\section{References}

1. Wisniewski, Z.; Blaszczyk, A. Changes in Maintenance Management Practices-Standards and Human Factor. Adv. Intell. Syst. Comput. 2018, 606, 348-354. [CrossRef]

2. GFMAN. The Maintenance Framework, 1st ed.; The Global Forum on Maintenance \& Asset Management (GFMAM): Kelowna, Canada, 2016.

3. Ihemegbulem, I.; Baglee, D. ISO55000 Standard as a Driver for Effective Maintenance Budgeting. In Proceedings of the 2nd International Conference on Maintenance Engineering, Manchester, UK, 5-6 September 2017; p. 16.

4. Ahuja, I.S.; Khamba, J. Total productive maintenance: Literature review and directions. Int. J. Qual. Reliab. Manag. 2008, 25, 709-756. [CrossRef]

5. Da Silva, R.F.; De Souza, G.F.M. Asset management system (ISO 55001) and Total Productive Maintenance (TPM): A discussion of interfaces for maintenance management. Revista Gestão da Produção Operações e Sistemas 2020, 15, 288-313. [CrossRef]

6. Haroun, A.E.; Duffuaa, S.O. Maintenance Organization; Springer: Singapore, 2009; pp. 3-15.

7. ISO. ISO 55000—Asset Management-Overview, Principles and Terminology; ISO: Geneva, Switzerland, 2014.

8. Wijnia, Y.; de Croon, J. The Asset Management Process Reference Model for Infrastructures. In 9th WCEAM Research Papers. Lecture Notes in Mechanical Engineering; Springer: Basel, Switzerland, 2015; pp. 447-457.

9. Okoh, P.; Schjølberg, P.; Wilson, A. AMMP: A new maintenance management model based on ISO 55000. Infrastruct. Asset Manag. 2016, 3, 21-28. [CrossRef]

10. ISO. ISO 55001—Asset Management-Management Systems—Requirements; ISO: Geneva, Switzerland, 2014.

11. Goodwin, P.; Wright, G. Decision Analysis for Management Judgements, 5th ed.; John Wiley and Sons Ltd.: Hoboken, NJ, USA, 2014.

12. Koornneef, H.; Verhagen, W.; Curran, R. A decision support framework and prototype for aircraft dispatch assessment. Decis. Support Syst. 2020, 135, 113338. [CrossRef]

13. Özcan, E.; Ünlüsoy, S.; Eren, T. A combined goal programming-AHP approach supported with TOPSIS for maintenance strategy selection in hydroelectric power plants. Renew. Sustain. Energy Rev. 2017, 78, 1410-1423. [CrossRef]

14. Melani, A.H.; Murad, C.A.; Netto, A.C.; Souza, G.F.; Nabeta, S.I. Maintenance Strategy Optimization of a Coal-Fired Power Plant Cooling Tower through Generalized Stochastic Petri Nets. Energies 2019, 12, 1951. [CrossRef]

15. Saaty, T.L. The Analytic Hierarchy Process: Planning Setting Priorities, Resource Allocation; McGraw-Hill: New York, NY, USA, 1980.

16. Bevilacqua, M.; Braglia, M. The analytic hierarchy process applied to maintenance strategy selection. Reliab. Eng. Syst. Saf. 2000, 70, 71-83. [CrossRef]

17. Belinelli, M.; Federal University of Technology; Zattar, I.C.; Da Silva, M.M.; Seleme, R.; De Souza, G.F.; Rodrigues, M.; De Oliveira, C.C.; Savoldi, A. Prioritization of the Industrial Maintenance Activities According its Ergonomics Risks using Multi-criteria Analysis AHP. Int. J. Eng. Trends Technol. 2018, 59, 214-222. [CrossRef]

18. Ayag, Z.; Samanlioglu, F. Fuzzy AHP-GRA approach to evaluating energy sources: A case of Turkey. Int. J. Energy Sect. Manag. 2020, 14, 40-58. [CrossRef]

19. Hwang, C.-L.; Yoon, K. Multiple Attribute Decision Making, 1st ed.; Springer: Berlin/Heidelberg, Germany, 1981.

20. Bai, C.; Dhavale, D.; Sarkis, J. Integrating Fuzzy C-Means and TOPSIS for performance evaluation: An application and comparative analysis. Expert Syst. Appl. 2014, 41, 4186-4196. [CrossRef]

21. Bertolini, M.; Esposito, G.; Romagnoli, G. A TOPSIS-based approach for the best match between manufacturing technologies and product specifications. Expert Syst. Appl. 2020, 159, 113610. [CrossRef]

22. Saaty, T.L. The Analytic Network Process: Decision Making with Dependence and Feedback; RWS Publications: Pittsburgh, PA, USA, 2001.

23. Zaim, S.; Turkyilmaz, A.; Acar, M.F.; Alturki, U.M.; Demirel, O.F. Maintenance strategy selection using AHP and ANP algorithms: A case study. J. Qual. Maint. Eng. 2012, 18, 16-29. [CrossRef]

24. Saaty, T.L.; Vargas, L.G. Decision Making with the Analytic Network Process; Springer Science and Business Media LLC: Berlin/Heidelberg, Germany, 2006; Volume 282.

25. Liu, P.C.Y.; Lo, H.-W.; Liou, J.J.H. A Combination of DEMATEL and BWM-Based ANP Methods for Exploring the Green Building Rating System in Taiwan. Sustainability 2020, 12, 3216. [CrossRef]

26. Opricovic, S.; Tzeng, G.-H. A comparative analysis of the DEA-CCR model and the VIKOR method. Yugosl. J. Oper. Res. 2008, 18, 187-203. [CrossRef]

27. Alinezhad, A.; Esfandiari, N. Sensitivity Analysis in the QUALIFLEX and VIKOR Methods. J. Optim. Ind. Eng. 2012, 10, 29-34.

28. Brans, J.P. L'ingénièrie de la décision; Elaboration d'instruments d'aide à la décision. La méthode PROMETHEE. In L'aide à la Décision Nature, Instruments Perspect. d'Avenir; Nadeau, R., Landry, M., Eds.; Presses de l'Université Laval: Québec, QC, Canada, 1982; pp. 183-213.

29. Brans, J.-P.; Mareschal, B. Promethee Methods. In Multiple Criteria Decision Analysis: State of the Art Surveys; International Series in Operations Research \& Management Science; Springer: New York, NY, USA, 2005; Volume 78. [CrossRef]

30. Chen, Y.-H.; Wang, T.-C.; Wu, C.-Y. Strategic decisions using the fuzzy PROMETHEE for IS outsourcing. Expert Syst. Appl. 2011, 38, 13216-13222. [CrossRef]

31. Charnes, A.; Cooper, W.W.; Rhodes, E. Measuring the efficiency of decision making units. Eur. J. Oper. Res. 1978, 2, 429-444. [CrossRef] 
32. Dyson, R.G.; Allen, R.; Camanho, A.S.; Podinovski, V.V.; Sarrico, C.S.; Shale, E.A. Pitfalls and Protocols in DEA. Eur. J. Oper. Res. 2001, 132, 245-259. [CrossRef]

33. Roy, B.; Vanderpooten, D. The European school of MCDA: Emergence, basic features and current works. J. Multi-Criteria Decis. Anal. 1996, 5, 22-38. [CrossRef]

34. Del Vasto-Terrientes, L.; Valls, A.; Slowinski, R.; Zielniewicz, P. ELECTRE-III-H: An outranking-based decision aiding method for hierarchically structured criteria. Expert Syst. Appl. 2015, 42, 4910-4926. [CrossRef]

35. Żak, J.; Kruszyński, M. Application of AHP and ELECTRE III/IV Methods to Multiple Level, Multiple Criteria Evaluation of Urban Transportation Projects. Transp. Res. Procedia 2015, 10, 820-830. [CrossRef]

36. Zavadskas, E.K.; Antucheviciene, J.; Saparauskas, J.; Turskis, Z. MCDM methods WASPAS and MULTIMOORA: Verification of robustness of methods when assessing alternative solutions. Econ. Comput. Econ. Cybern. Stud. Res. 2013, 47, 5-20.

37. Chakraborty, S.; Zavadskas, E.K. Applications of WASPAS Method in Manufacturing Decision Making. Informatica 2014, 25, 1-20. [CrossRef]

38. Siksnelyte, I.; Zavadskas, E.K.; Streimikiene, D.; Sharma, D. An Overview of Multi-Criteria Decision-Making Methods in Dealing with Sustainable Energy Development Issues. Energies 2018, 11, 2754. [CrossRef]

39. Huang, I.B.; Keisler, J.; Linkov, I. Multi-criteria decision analysis in environmental sciences: Ten years of applications and trends. Sci. Total Environ. 2011, 409, 3578-3594. [CrossRef] [PubMed]

40. Velasquez, M.; Hester, P.T. An analysis of multi-criteria decision making methods. Int. J. Oper. Res. 2013, 10, 56-66.

41. Kabir, G.; Sadiq, R.; Tesfamariam, S. A review of multi-criteria decision-making methods for infrastructure management. Struct. Infrastruct. Eng. 2014, 10, 1176-1210. [CrossRef]

42. Behzadian, M.; Otaghsara, S.K.; Yazdani, M.; Ignatius, J. A state-of the-art survey of TOPSIS applications. Expert Syst. Appl. 2012, 39, 13051-13069. [CrossRef]

43. Baumann, M.; Weil, M.; Peters, J.; Chibeles-Martins, N.; Moniz, A. A review of multi-criteria decision making approaches for evaluating energy storage systems for grid applications. Renew. Sustain. Energy Rev. 2019, 107, 516-534. [CrossRef]

44. Gul, M.; Celik, E.; Aydin, N.; Gumus, A.T.; Guneri, A.F. A state of the art literature review of VIKOR and its fuzzy extensions on applications. Appl. Soft Comput. 2016, 46, 60-89. [CrossRef]

45. Pohekar, S.; Ramachandran, M. Application of multi-criteria decision making to sustainable energy planning-A review. Renew. Sustain. Energy Rev. 2004, 8, 365-381. [CrossRef]

46. Sabaei, D.; Erkoyuncu, J.; Roy, R. A Review of Multi-criteria Decision Making Methods for Enhanced Maintenance Delivery. Procedia CIRP 2015, 37, 30-35. [CrossRef]

47. Cinelli, M.; Coles, S.R.; Kirwan, K. Analysis of the potentials of multi criteria decision analysis methods to conduct sustainability assessment. Ecol. Indic. 2014, 46, 138-148. [CrossRef]

48. Durbach, I.N.; Stewart, T.J. Modeling uncertainty in multi-criteria decision analysis. Eur. J. Oper. Res. 2012, 223, 1-14. [CrossRef]

49. Bouyssou, D. Using DEA as a Tool for MCDM: Some Remarks. J. Oper. Res. Soc. 1999, 50, 974. [CrossRef]

50. Opricovic, S.; Tzeng, G.-H. Comparing DEA and MCDM Method; Springer: Singapore, 2003; pp. $227-232$.

51. Sarkis, J. A comparative analysis of DEA as a discrete alternative multiple criteria decision tool. Eur. J. Oper. Res. 2000, 123, 543-557. [CrossRef]

52. Kheybari, S.; Rezaie, F.M.; Farazmand, H. Analytic network process: An overview of applications. Appl. Math. Comput. 2020, 367, 124780. [CrossRef]

53. Si, S.-L.; You, X.-Y.; Liu, H.-C.; Zhang, P. DEMATEL Technique: A Systematic Review of the State-of-the-Art Literature on Methodologies and Applications. Math. Probl. Eng. 2018, 2018, 1-33. [CrossRef]

54. Haddad, M.; Sanders, D. Selection of discrete multiple criteria decision making methods in the presence of risk and uncertainty. Oper. Res. Perspect. 2018, 5, 357-370. [CrossRef]

55. Guitouni, A.; Martel, J.-M. Tentative guidelines to help choosing an appropriate MCDA method. Eur. J. Oper. Res. 1998, 109, 501-521. [CrossRef]

56. Leite, I.M.S.; de Freitas, F.F.T. Análise Comparativa dos Métodos de Apoio Multicritério a Decisão: AHP, ELECTRE e PROMETHEE XXXII Encontro Nac. Eng. Produção, Bento Gonçalves, RS: 2012. Available online: http://www.abepro.org.br/biblioteca/ enegep2012_TN_STP_162_944_20906.pdf (accessed on 26 August 2020).

57. Haddad, M.; Sanders, D.; Tewkesbury, G. Selecting a discrete multiple criteria decision making method for Boeing to rank four global market regions. Transp. Res. Part A Policy Pract. 2020, 134, 1-15. [CrossRef]

58. Banihabib, M.E.; Hashemi-Madani, F.-S.; Forghani, A. Comparison of Compensatory and non-Compensatory Multi Criteria Decision Making Models in Water Resources Strategic Management. Water Resour. Manag. 2017, 31, 3745-3759. [CrossRef]

59. Zavadskas, E.K.; Turskis, Z. A new logarithmic normalization method in games theory. Informatica 2008, 19, 303-314. [CrossRef]

60. Vafaei, N.; Ribeiro, R.A.; Camarinha-Matos, L. Data normalisation techniques in decision making: Case study with TOPSIS method. Int. J. Inf. Decis. Sci. 2018, 10, 19. [CrossRef]

61. Jahan, A.; Edwards, K.L. A state-of-the-art survey on the influence of normalization techniques in ranking: Improving the materials selection process in engineering design. Mater. Des. 2015, 65, 335-342. [CrossRef]

62. Çelen, A. Comparative Analysis of Normalization Procedures in TOPSIS Method: With an Application to Turkish Deposit Banking Market. Informatica 2014, 25, 185-208. [CrossRef] 
63. Chan, F.T.; Prakash, A. Maintenance policy selection in manufacturing firms using the fuzzy MCDM approach. Int. J. Prod. Res. 2012, 50, 7044-7056. [CrossRef]

64. Kahraman, C.; Onar, S.C.; Oztaysi, B. Fuzzy Multicriteria Decision-Making: A Literature Review. Int. J. Comput. Intell. Syst. 2015, 8, 637-666. [CrossRef]

65. Bevilacqua, M.; Ciarapica, F.E.; Mazzuto, G. A Fuzzy Cognitive Maps Tool for Developing a RBI\&M Model. Qual. Reliab. Eng. Int. 2016, 32, 373-390. [CrossRef]

66. Saaty, T.L.; Vargas, L.G. Models, Methods, Concepts E Applications of the Analytic Hierarchy Process; Springer: New York, NY, USA, 2012 ; p. 345.

67. Saaty, T.L. Decision making-The Analytic Hierarchy and Network Processes (AHP/ANP). J. Syst. Sci. Syst. Eng. 2004, 13, 1-35. [CrossRef]

68. Da Silva, R.F.; Melani, A.H.A.; Michalski, M.A.; de, C.; de Souza, G.F.M.; Nabeta, S.I. Defining maintenance significant items based on ISO 55000 and AHP: A hydropower plant case study. In Proceedings of the 29th European Safety and Reliability Conference, Hannover, Germany, 22-26 September 2019; pp. 3437-3444.

69. Şengül, Ü.; Eren, M.; Shiraz, S.E.; Gezder, V.; Şengül, A.B. Fuzzy TOPSIS method for ranking renewable energy supply systems in Turkey. Renew. Energy 2015, 75, 617-625. [CrossRef]

70. Wei, C.-C.; Cheng, Y.-L.; Lee, K.-L. How to select suitable manufacturing information system outsourcing projects by using TOPSIS method. Int. J. Prod. Res. 2019, 57, 4333-4350. [CrossRef]

71. Conejero, J.; Preciado, J.; Prieto, A.; Bas, M.; Bolós, V. Applying data driven decision making to rank vocational and educational training programs with TOPSIS. Decis. Support Syst. 2021, 142, 113470. [CrossRef] 